\title{
BASIC TRAINING LEADERSHIP MANAGEMENT FOR STUDENT
}

\author{
AGUS FAHMI ${ }^{1}$, HARDIANSYAH ${ }^{2}$, MENIK ARYANI ${ }^{3}$, AHMAD MUSLIM ${ }^{4}$ \\ Program Studi Administrasi Pendidikan FIPP UNDIKMA \\ Coresponding Author: fahmi_ap@ikipmataram.ac.id
}

\begin{abstract}
ABSTRAK
Pendidikan merupakan bagian terpenting dalam penyelenggaraan suatu negara sebagai unsur utama perubahan kearah yang lebih baik. Pembukaan UUD 1945 telah mengamanatkan bahwa tujuan utama indonesia Merdeka adalah "Mencerdaskan Kehidupan Bangsa" artinya, pemenuhan kebutuhan pendidikan bagi setiap insan yang hidup di bumi nusantara merupakan tanggungjawab penuh negara. Pada pelaksanaannya, pendidikan dituntut untuk melaksanakan kegiatan yang dapat memacu dan mewujudkan peserta didik yang tangguh, beriman kepada Tuhan Yang Maha Esa, Cerdas, terampil, serta memiliki jiwa kepemimpinan yang baik. Oleh karena itu, pelatihan manajemen kepemimpinan dasar bagi siswa sangatlah penting untuk dilaksanakan mengingat bahwa perkembangan Zaman dan Teknologi akan menggerus jiwa kritis, percaya diri, inisiatif, dan kepekaan sosial. Pelatihan manajemen kepemimpinan ini akan menggunakan metode ceramah atau penyuluhan dan simulasi atau permainan yang melatih untuk berpikir kritis. Pelaksanaan kegiatan pelatihan dasar management kepemimpinan untuk siswa ini diharapkan dapat mewujudkan siswa yang mampu berpikir kritis, memiliki kecintaan dan ketakwaan Kepada Tuhan Yang Maha Esa, mampu mengelola konflik dan emosi, memiliki inisiatif untuk pemecahan masalah, dan selalu menghargai pendapat orang lain, serta memiliki kepekaan sosial yang tinggi.
\end{abstract}

Kata Kunci: Pelatihan Dasar, Manajemen Kepemimpinan, Siswa

\section{ABSTRACT}

Education is the most important part in running a country as the main element of change for the better. The preamble to the 1945 Constitution has mandated that the main objective of Free Indonesia is "Educating the Nation's Life" meaning that meeting the educational needs of every human being living on the archipelago is the full responsibility of the state. In its implementation, education is required to carry out activities that can stimulate and create students who are strong, have faith in God Almighty, are intelligent, skilled, and have a good leadership spirit. Therefore, basic leadership management training for students is very important to be carried out considering that the development of the Age and Technology will erode the critical spirit, self-confidence, initiative, and social sensitivity. This leadership management training will use lectures or outreach methods and simulations or games that train critical thinking. The implementation of basic leadership management training activities for students is expected to be able to create students who are able to think critically, have love and devotion to God Almighty, are able to manage conflicts and emotions, have the initiative to solve problems, and always respect the opinions of others, and have sensitivity. high social. Keywords: Basic Training, Leadership Management, Student

\section{PENDAHULUAN}

Masalah kepemimpinan adalah masalah yang utama dalam hidup dan kehidupan umat manusia, oleh karena itulah maka umat manusia selalu membutuhkan kepemimpinan, sebab untuk mencapai suksesnya sebuah tujuan dan terjadinya efisiensi kerja harus ada pemimpin. Kepemimpinan merupakan kekuatan aspirasional, kekuatan semangat, dan kekuatan moral yang kreatif yang mampu mempengaruhi para anggota untuk mengubah sikap, sehingga mereka menjadi konform dengan keinginan pemimpin. Untuk itu, maka gaya seseorang di dalam memimpin akan amat berpengaruh terhadap organisasi atau lembaga yang dipimpinnya, baik pengaruh itu bersifat positif maupun negatif terhadap organisasi tersebut. Covey menyatakan bahwa 90 persen dari semua kegagalan kepemimpinan adalah kegagalan pada karakter. 


\section{COMMUNITY : Jurnal Pengabdian Kepada Masyarakat Vol. 1 No. 1 Mei 2021 e-ISSSN : 2797-0159 | p-ISSN : 2797-0574}

Kepemimpinan adalah pangkal utama dan pertama penyebab daripada suatu kegiatan, proses atau kesediaan untuk merubah pandangan atau sikap daripada kelompok orang-orang, baik dalam hubungan organisasi formal maupun informal.

Kepemimpinan merupakan suatu kekuatan penting dalam rangka pengelolaan suatu lembaga atau organisasi, sehingga kemampuan seseorang pemimpin secara efektif merupakan kunci keberhasilan suatu lembaga atau organisasi. Maka, esensi kepemimpinan adalah kepengikutan, kemauan orang lain untuk mengikuti keinginan pemimpin. Pemimpin merupakan faktor penentu dalam kesuksesan atau gagalnya suatu organisasi dan usaha. Baik di dunia bisnis, maupun di dunia pendidikan, kesehatan, perusahaan, religi, sosial, politik, pemerintahan Negara, dan lain-lain, kualitas pemimpin menentukan keberhasilan lembaga atau organisasinya. Sebab, kepemimpinan yang baik adalah kepemimpinan yang mampu membawa suatu lembaga atau organisasi sesuai dengan asas-asas manajemen sekaligus bersedia memberikan kesejahteraan dan kebahagiaan kepada bawahan dan masyarakat luas.

Secara eksplisit konsep kepemimpinan sudah disinggung oleh Al-Qur'an bahwa kepemimpinan merupakan missen sacre (tugas suci) terhadap pembangunan manusia, tugas ini merupakan bentuk manifestasi manusia sebagai khalifah fil al ardh (wakil Allah dimuka bumi) untuk jadi pemimpin (khalifah). Manajemen Kepemimpinan adalah seni untuk mengelola kemampuan seseorang dalam memimpin, mengarahkan dan mengajak orang lain menuju tujuan dengan cara yang efisien dan efektif. Seorang pemimpin yang mempunyai cita-cita besar bisa menghidupkan satu kaum (bangsa). Kepemimpinan diartikan sebagai: Orang yang memiliki kemampuan mempengaruhi (karena wibawa, pengetahuan atau dapat melakukan komunikasi), dan mengkoordinasikan untuk mengarahkan orang-orang yang dipimpinnya, serta untuk mencapai tujuan

Pemimpin yang baik menyadari bahwa ia juga harus menjadi pengikut yang baik. Boleh dikatakan, pemimpin juga harus melapor kepada seseorang atau kelompok. Oleh sebab itu mereka juga harus menjadi pengikut yang baik. Pengikut yang baik harus menghindari persaingan dengan pemimpin, bertindak dengan setia, dan menanggapi ide, nilai dan tingkah laku pemimpin secara konstruktif. Pemimpin adalah seseorang yang mau dipimpin. Pemimpin harus senantiasa memberi perhatian pada kesejahteraan bawahan/anggotanya.

Kepemimpinan merupakan bagian penting dari manajemen yaitu merencanakan dan mengorganisasikan, tetapi peran utama kepemimpinan adalah mempengaruhi orang lain untuk mencapai tujuan yang telah ditetapkan. Hal ini merupakan bukti bahwa pemimpin boleh jadi manajer yang lemah apabila perencanaannya jelek yang menyebabkan kelompok berjalan ke arah yang salah. Akibatnya walaupun dapat menggerakkan tim kerja, namun mereka tidak berjalan ke arah yang salah, namun mereka tidak berjalan kea rah pencapaian tujuan organisasi. Kepemimpinan berkaitan dengan proses yang mempengaruhi orang sehingga mereka mencapai sasaran dalam keadaan tertentu. Kepemimpinan telah digambarkan sebagai penyelesaian pekerjaan melalui orang atau kelompok dan kinerja manajer akan tergantung pada kemampuannya sebagai manajer. Hal ini berarti mampu mempengaruhi terhadap orang atau kelompok untuk mencapai hasil yang diinginkan dan ditetapkan bersama.

\section{METODE PENGABDIAN}

Metode yang diterapkan dalam pelatihan ini, yaitu metode presentasi, metode demonstrasi, dan metode praktik. Metode presentasi dalam kegiatan ini untuk menjelaskan teori dan perspektif ilmiah tentang pentingnya personal leadership. Metode Demonstrasi bertujuan untuk mengenal karakteristik masing-masing siswa yang menjadi peserta Pelatihan. Sedangkan metode praktik dimaksudkan untuk menggali kemampuan dan spesifikasi pemahaman siswa dalam mengimplementasikannya secara nyata.

\section{HASIL PENGABDIAN DAN PEMBAHASAN}

1. Persiapan

1) Mekanisme pelaksanaan kegiatan PKM 
2) Persiapan Materi Basic Training Leadership Management For Student

3) Pembuatan Modul

2. Pelaksanaan Program

Adapun pelaksanaan kegiatan Pengabdian ini adalah sebagai berikut:

a. Melakukan analisis tentang aktivitas Sekolah

b. Analisis masalah sekolah

c. Penyusunan modul diklat

d. Perbanyakan modul sesuai dengan jumlah peserta.

e. Program Pelatihan Basic Training Leadership Management For Student yang pertama adalah proses perkenalan dan pemberian materi diklat. Kegiatan matrikulasi dilakukan 1 kali pertemuan dengan waktu 4 jam untuk setiap pertemuan.

f. Pelaksanaan Kegiatan mandiri dengan pola kerja yang telah dipelajari.

g. Kegiatan evaluasi perkembangan program

h. Program monitoring

i. Volume pelaksaan PKM yang dilakukan.

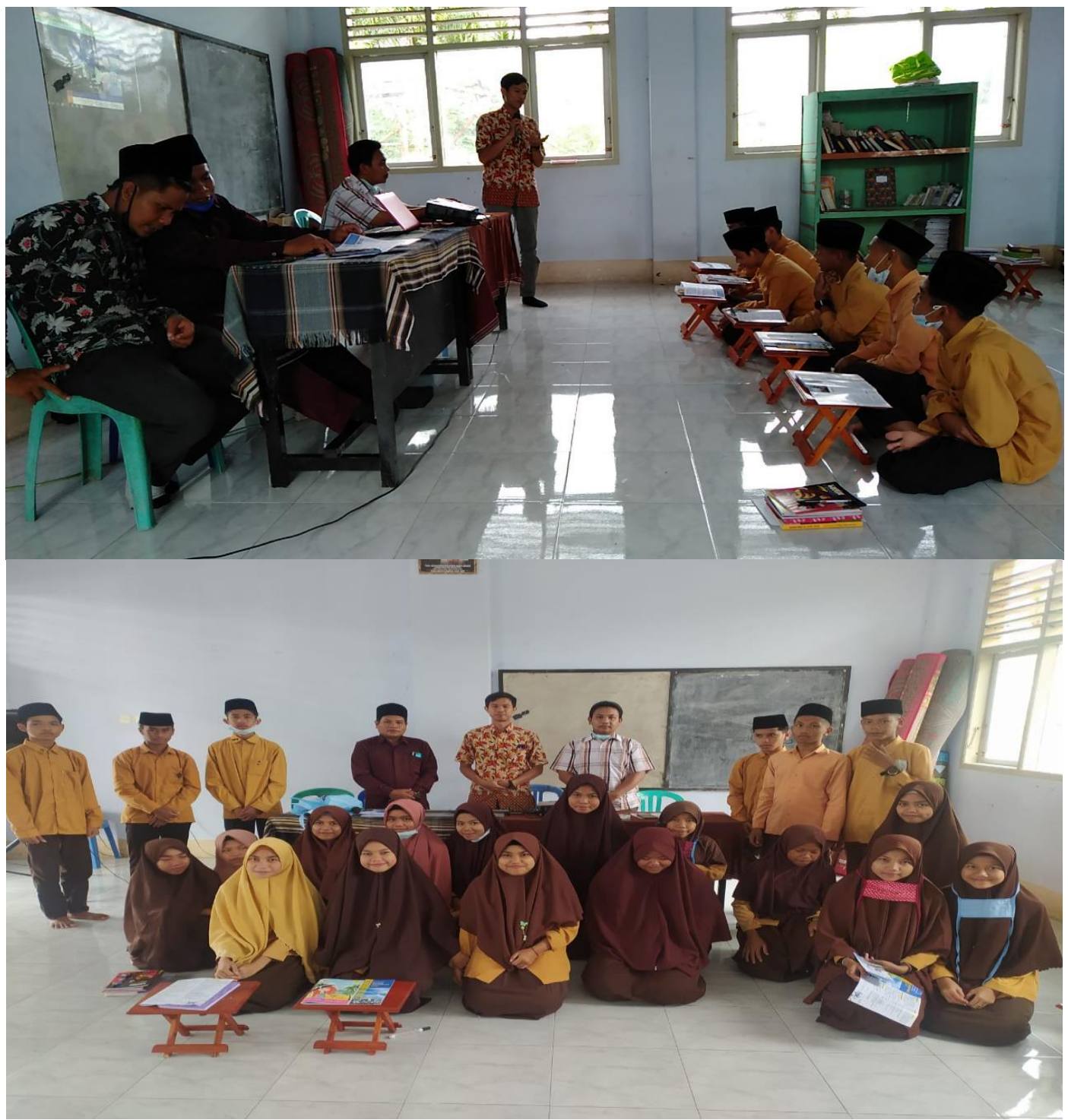

\section{Gambar 1. Dokumentasi Kegiatan Pelatihan}

Permainan-permainan yang memiliki nilai kepemimpinan, seperti :

a. Memasukkan paku dalam botol dengan mata tertutup. Salah seorang yang lain memberikan aba-aba agar paku tersebut masuk. Dibutuhkan kemampuan untuk 
menganalisis segala macam kemungkinan dan kemampuan untuk memerintah secara hati-hati dan terpertimbangkan agar bisa mencapai goal dari permainan ini yaitu memasukkan paku dalam botol.

b. Bisik berantai. Dibutuhkan kemampuan sebagai pendengar sekaligus penyampai pesan yang baik agar dapat menyampaikan pesan yang benar dari awal hingga akhir.

Pemberian materi kepemimpinan yang dibagi dalam beberapa sesi, seperti :

a. Sesi Kepemimpinan : Penyuluhan mengenai karakter pemimpin yang benar.

b. Sesi Komunikasi : Penyuluhan mengenai cara-cara berkomunikasi yang benar sebagai layaknya seorang pemimpin.

c. Sesi Problem Solving / Challange - Proses manajemen konflik : Penyuluhan mengenai cara-cara seorang pemimpin memecahkan masalah secara efektif dan benar.

d. Sesi Dinamika Kelompok : Berupa permainan.

Pelaksanaan program pengabdian tentang personal leadership merupakan pembentukan karakter pemimpin sejak usia muda. Sehingga dapat berperan aktif baik di lingkungan kelas, sekolah, keluarga, dan di lingkungan masyarakat. Terlebih lagi, penemuan jati diri, kedisiplinan, penghargaan, daya juang, kerja sama, tanggung jawab, kerendahan hati dan motivasi serta komitmen pribadi.

Tujuan diadakannya latihan kepemimpinan dasar ini adalah :

1. Siswa dapat mengenali jati dirinya : kelemahan dan kekuatan dirinya.

2. Siswa dapat mengenal pribadi orang lain dan mampu menempatkan diri di hadapan orang lain dengan baik dan bertanggung jawab.

3. Siswa menyadari akan sikap hidup yang positif

4. Siswa mampu menyusun langkah-langkah nyata bagi hidupnya dalam rangka untuk menjadi pemimpin bagi dirinya sendiri.

Untuk mengawali kegiatan workshop Personal Leadership For Student diberikan pemahaman yakni dalam tingkatan ilmiah kepemimpinan itu dipandang sebagai suatu fungsi, bukan sebagai kedudukan atau pembawaan pribadi seseorang. Maka diadakanlah suatu analisa tentang unsur-unsur dan fungsi yang dapat menjelaskan kepada kita, syarat-syarat apa yang diperlukan agar pemimpin dapat bekerja secara efektif dalam situasi yang berbeda-beda. Pandangan baru ini membawa perubahan besar. Cara bekerja dan sikap seorang pernimpin dipelajari. Cara melatih pemimpin-pemimpin diubah. Orang mempelajari lebih banyak aspek kehidupan dalam kelompok. Ada yang memusatkan perhatian terhadap hubungan insani dalam kelompok. Ada pula yang memperhatikan organisasi kelompok, aspek perasaan atau emosi, struktur kekuasaan dan wibawa antar anggota, proses pengambilan keputusan, pola komunikasi, fungsi pemimpin dan yang dipimpin.

Level Konseptualisasi Kepemimpinan

1) Proses Individual

Potensi kontribusi dari pendekatan intra individu terhadap kepemimpinan sangatlah terbatas, karena tidak mencakup sebagian besar teori yang dianggap merupakan proses penting dari kepemimpinan, yaitu pengaruh atas orang lain. Dalam studi tentang ciri kepemimpinan yang tidak membahas perilaku pemimpin dan proses pengaruh, sulit menentukan mengapa beberapa ciri atau keterampilan itu berhubungan dengan efektivitas atau kemajuan kepemimpinan. Pengetahuan tentang proses intra individu memberikan beberapa pemahaman yang membantu dalam menyusun teori kepemimpinan yang lebih baik, tetap teori itu sendiri sebaiknya tidak berfokus pada level ini.

2) Proses Dyadic 
Fokus dari pendekatan dyadic adalah pada hubungan antara seorang pemimpin dan individu lain yang biasanya merupakan seorang pengikut. Sebagian besar teori dyadic memandang kepemimpinan sebagai proses pengaruh timbal balik antara pemimpin dengan orang lain.

3) Proses Kelompok

Pandangan lain mengenai kepemimpinan memandang kepemimpinan sebagai proses kelompok. Dua topik utamanya adalah sifat peran kepemimpinan dalam tugas kelompok dan bagaimana kontribusi pemimpin terhadap efektivitas kelompok.

4) Proses Organisasi

Kelangsungan hidup dan kemakmuran organisasi tergantung pada efektivitas adaptasi terhadap lingkungan, yang berarti berhasil memasarkan outputnya (barang dan jasa), memperoleh sumber yang dibutuhkan, dan menghadapi ancaman eksternal. Adaptasi membaik dengan mengantisipasi kebutuhan dan keinginan pelanggan, selalu meninjau tindakan dan rencana competitor, selalu mngevaluasi kemungkinan kendala dan ancaman, dan mengidentifikasi prosuk dan jasa yang dapat dipasarkan dimana organisasi mempunyai kemampuan unik untuk memenuhinya.

Pemberian materi kepemimpinan khususnya tentang leadership management dapat diterima dengan baik oleh seluruh siswa yang mengikuti kegiatan pelatihan, sehingga ketajaman pemahaman dapat didalami secara komprehensif. Demikian juga ketika menjalankan sebuah oraganisasi sepeti Osis, Pramuka, UKS, dan seterusnya dapat menerapkan fungsi esensial kepemimpinan agar membantu organisasi beradaptasi dengan lingkungan dan mendapatkan sumber-sumber yang dibutuhkan untuk bertahan hidup. Tanggung jawab kepemimpinan disini adalah mendesain struktur organisasi yang tepat, menentukan hubungan kewenangan dan mengkoordinasikan proses antar spesialisasi sub-unit dalam organisasi.

Sebagai bahan evaluasi dalam pelatihan ini maka Muncul secara tidak langsung apabila ingin mengetahui apakah sebabnya seseorang yang dicalonkan untuk seorang pemimpin pada akhirnya tidak terpilih dalam hubungan ini ada dua pendapat tentang persyaratan menjadi pemimpin itu, yaitu sebagai berikut :

1. Bahwa setiap orang yang sudah dewasa dengan sendirinya dapat menjadi pemimpin dalam kelompok. Dewasa dalam hal ini diukur berdasarkan umurnya. Maksudnya, apabila akan ditentukan siapakah yang cocok untuk memimpin sebuah kelompok, maka dia yang tertua yang dipilih. Dipilihnya yang tertua sebagai pemimpin kelompok bisanya berdasarkan beberapa pertimbangan, antara lain:

a) Yang tertua mempunyai pengalaman terbanyak, sebab dia sudah lebih lama hidup dibandingkan dengan yang lainnya (pengalaman hidup). Pengalaman hidup yang lama dapat membentuk pribadi yang kuat, sehingga stabilitas emosional lebih mungkin terdapat pada orang yang tertua usianya. Stabilitas emosional merupakan salah satu syarat penting yang banyak dituntut oleh seorang pemimpin.

b) Yang tertua secara emosional memungkinkan seseorang anggota memperoleh perlindungan lebih-lebih dalam suasana kebapak-an (paternalistik) dimana seorang pemimpin

2. bahwa tidak setiap orang begitu saja bisa menjadi pemimpin melainkan hanya bisa dipercayakan kepada orang-orang tertentu saja. Pendapat ini menegaskan, bahwa seorang pemimpin itu bukan orang begitu saja, tetapi memang orang pilihan (selected). Jadi tidak hanya sekedar tua umur saja, melainkan masih banyak syarat lain yang harus dipenuhi, yang pada pokoknya yang menyebabkan orang-orang menaruh kepercayaan kepada orang tersebut untuk bisa memimpin. Ini disebabkan karena :

a) Orang yang mempunyai umur paling tua belum tentu mampu memimpin, berdasarkan umur sudah tentu yang tertua berarti yang terlama hidup, akan tetapi 
belum tentu hidupnya diisi dengan pengalaman-pengalaman yang secara kualitatif berguna untuk memimpin kelompok.

b) Seorang pemimpin itu "menentukan" arah dan proses perjalanan kelompok, sehingga tidak sembarang orang bisa memimpin (dipercaya memimpin). Jika tidak selektif dikhawatirkan arah dan proses kehidupan kelompok akan rusak.

\section{KESIMPULAN}

Masalah kepemimpinan adalah masalah yang utama dalam hidup dan kehidupan umat manusia, oleh karena itulah maka umat manusia selalu membutuhkan kepemimpinan, sebab untuk mencapai suksesnya sebuah tujuan dan terjadinya efisiensi kerja harus ada pemimpin. Mendahului kegiatan dengan memberikan pemahaman tentang konsep dasar kepemimpinan yang dapat membentuk karakter dan kepribadian Siswa sehingga mereka mampu menjadi pribadi yang berakhlak mulia, santun, cekatan dalam bertindak, berkomunikasi dengan baik, memiliki pendirian yang kuat, dan berani bertanggungjawab secara sosial dan organisasi. Workshop ini memberikan manfaat yakni: 1) Kepada siswa dalam menghadapi tantangan zaman yang semakin kompetitif diharapkan karakter personal leadership menjadi benteng kokoh sebagai penopang sendi-sendi kehidupannya. 2) Pengaplikasian nilai-nilai kepemimpinan yang ditunjukkan pada tingkah laku siswa baik di sekolah maupun dalam lingkungan keluarga dan masyarakat. 3) menjadi pribadi yang tangguh dan memiliki sense of the future atau dapat menyongsong masa depan yang lebih baik. Demikianlah kegiatan workshop ini dilaksanakan dengan sangat apresiatif dari pihak sekolah dan masyarakat yang menginginkan adanya kegiatan lanjutan, sehingga kontinuitas kegiatan ini dapat diterapkan pada setiap tingkatan Siswa setiap tahunnya.

\section{DAFTAR PUSTAKA}

A.F. Stoner . 2013,Best for Teamwork: The Five Dysfunctions of a Team: A Leadership Fabe,Jilid 1 dan 2, Intermedia, Jakarta

Firmansyah, Hilman \& Syamsudin, Acep. 2016. Organisasi dan Manajemen Bisnis. Ombak, Yogyakarta.

Hadfield, S dan Hasson, G. 2013. Bersikap Tegas dalam Segala Situasi. Jakarta: BIP Kelompok Gramedia.

Khan (Diterjemahkan oleh Suwanto dan Doni Juni Priansa). 2014. You Are A Leader! Menjadi Pemimpin dengan memanfaatkan Potensi Terbesar yang Anda Miliki, PT. Elek Media Komputindo, Jakarta.

Murdoko, E.W.H. 2013. The Leader in You. Jakarta: ElexMedia Komputindo

Robbins, Stephen P. \& Coulter, Mary. (2014). Management, 11th ed. New Jersey: Pearson Education, Inc.

Samino. 2012. Kepemimpinan Pendidikan. Solo : Fairuz Media.

Wijayanto, Dian. 2015. Pengantar Manajemen, PT. Gramedia Pustaka Utama, Jakarta. 